\title{
Ion Mării, Harta lexicală semantică, Editura Clusium, Cluj-Napoca, 2002, 189 p.
}

\author{
Dinu Moscal* \\ Institutul de Filologie Română „A. Philippide”, Str. Th. Codrescu 2, 700481 Iași, România
}

Lucrarea lui I. Mării abordează cele trei domenii anunţate prin titlu, obiectivul vizat fiind domeniul dialectologiei, indicat prin determinatul harta, ordinea determinanților arătînd ordinea aplicației în dialectologie a teoriilor și rezultatelor din celelalte două domenii. Pe scurt, este vorba despre aplicarea judicioasă a semanticii structurale dezvoltate prin direcția Saussure-Trubetzkoy/Hjelmslev-Coseriu în abordarea lexicului și trecerea acestei perspective în modul de prelucrare a datelor obținute în anchetele dialectale pentru atlasele lingvistice române (seriile ALR), la care se adaugă și repercusiunile la nivelul dicționarelor care folosesc datele din seriile ALR, în primul rînd Dicţionarul limbii române (DLR).

Scopul lucrării este analiza dintr-o perspectivă critică a metodei de lucru și a rezultatelor din lucrările menționate. Perspectiva critică trebuie înțeleasă în accepția pur științifică, obiectivul fiind înțelegerea și ameliorarea rezultatelor din lucrările de dialectologie și de lexicografie reprezentative. În introducere, autorul prezintă într-un mod clar intențiile acestei analize, numită „critică evaluativă constructivă” (p. 1011). Observațiile făcute pe parcursul lucrării se bazează pe activitatea de peste patru decenii a autorului în domeniul dialectologiei și al lexicografiei.

În ceea ce privește stilul, fraza are de multe ori un grad ridicat de complexitate, cu propoziţii intercalate, cu paranteze explicative uneori destul de consistente şi cu un număr relativ mare de trimiteri, combinaţia acestor trăsături într-o singură frază solicitînd atenția cititorului. În ceea ce privește nivelul de limbă, autorul trece de multe ori la nivelul limbajului familiar sau al celui popular, ca instrument de punere în evidență a veridicităţii și incontestabilităţii unor evaluări sau observații științifice.

Cititorul va remarca imediat că elementele de bază pentru interpretarea rezultatelor din ancheta dialectală sînt o bună cunoaștere a distincțiilor evidențiate de Coseriu în studiile sale de semantică şi a modalității în care se obțin și se consemneză datele dialectale, majoritatea notelor de la capitolul introductiv explicînd aceste două lucruri. Mării pledează pentru o interpretare și o redare a materialului dialectal pornind de la conţinutul semantic (lexical) al termenilor, motiv pentru care o hartă constituită pe acest principiu este numită „hartă lexicală semantică”, aceasta deosebindu-se de harta lexicală onomasiologică (propusă în ALR), care pornește de la nivelul ontologic (denumirile unei realități). Avantajul unei asemenea abordări este cunoașterea lipsită de confuzii a conținutului fiecărui cuvînt obținut în anchetele dialectale. Exemplul studiat detaliat în capitolul al doilea este opoziția semantică sîmbure ${ }^{1}$ : simbure ${ }^{2}$, prezentă în Oltenia și, parțial, în Banat, care corespunde opoziției de conținut 'noyau de la prune' : 'amande du noyau de la prune'. Astfel, în sudul Olteniei avem opoziția simbure 'noyau de la prune' : miez 'amande du noyau de la prune', iar în nordul Olteniei avem opoziția os 'noyau de la prune' : sîmbure 'amande du noyau de la prune’. Cele două hărți onomasiologice pentru simbure ${ }^{1}$ și sîmbure ${ }^{2}$ din ALR nu surprind valoarea (în sens saussurean) cuvîntului, însă prezentarea opoziției simbure ${ }^{1}$ : sîmbure ${ }^{2}$ într-o singură hartă, unde apar notate în fiecare punct în care apar opozițiile sîmbure ${ }^{1}$ : miez și os : sîmbure ${ }^{2}$ oferă claritate și exactitate. În plus, o asemenea perspectivă obligă realizatorul unei hărți să țină cont de astfel de distincții atunci cînd interpretează materialul dialectal, dar și pe anchetator în receptarea materialului dialectal. Autorul constată o îmbunătățire în acest sens în NALR.

Autorul consideră că unul dintre punctele cheie în interpretatea corectă a termenilor dialectali este folosirea întrebării indirecte din perspectiva onomasiologică lexicală (prin care se obține numele unui concept) în defavoarea perspectivei onomasiologice referenţiale (prin care se obține numele unui obiect).

*Adresă de corespondență: dinumoscal@yahoo.com. 
Un exemplu, la care revine de mai multe ori, este răspunsul primit la întrebarea „În ce se păstrează brînza?”, și anume termenul găleată. Vasile T,âra îl interpretează ca fiind o „extensiune semantică”, în timp ce Mării consideră că „termenul găleată nu a suferit, în acest caz, nici un fel de extensiune semantică, ci obiectul numit găleată are și o asemenea întrebuințare, utilizare" (p. 59, cf. și p. 60, 67, 160). Autorul dă mai multe exemple de acest fel, considerînd că avem a face cu o confuzie între cuvinte și lucruri, ceea ce ar genera "grave denaturări lexicale onomasiologice și/sau semasiologice”. Teoretic, interpretarea dată de Mării poate fi susținută, însă este greu de presupus că dialectologii care au făcut ancheta și au primit astfel de răspunsuri (nu puține, după numărul exemplelor excerptate de Mării) ar fi putut face asemenea confuzii, iar acestea să fie perpetuate într-un mod neglijent de către redactorii ALR sau NALR. Astfel de situații pot fi cel mult asimilate procesului de neutralizare lexicală (amitit la p. 38). În realitate, este vorba despre o altă limbă funcțională, unde o anumită distincție poate să nu fie lexicalizată. De exemplu, într-o altă analiză (p. 41-46, 137-143), sint avute în vedere legăturile de rudenie desemnate la nivelul limbii române literare prin cumnat, fără să se distingă între conceptele 'fratele soției', 'soțul surorii' și 'soțul surorii soției'. Însă lucrurile nu stau în același fel la nivelul unor dialecte, unde distincțiile conceptuale menționate sînt lexicalizate în diferite moduri. Lipsa distincției de la nivelul limbii literare nu poate $f i$ explicată prin raportare la dialectele actuale. Doar asimilarea acestora cu un stadiu mai vechi al limbii române poate sluji ca o explicație în plan diacronic. În acelaşi fel stau lucrurile și într-o situaţie inversă, cum este cazul pentru găleată, în exemplul de mai sus. Astfel de „denaturări” apar în mod regulat întrun atlas și relevă de fapt natura limbii. Fără astfel de „denaturări” o limbă nu ar avea o istorie. Dăm aici un alt exemplu din aceeași categorie. La întrebarea 344, „Cum îi spui la vasul cu fundul rotund (gest) în care faceți mămăligă ?”, harta din ALR Trans. III indică în întreaga zonă, pe lîngă ceaun, și căldare, căldăruşă, căldăruţă. Conform raționamentului propus la răspunsul găleată pentru întrebarea „În ce se păstrează brînza?”, s-ar deduce că în Trasilvania mămăliga se face și în căldare, cu sensul pe care i-l atribuim dintr-o altă perspectivă, eventual din cea a românei literare. $\mathrm{O}$ „neconcordanță” a nivelului dialectal cu cel al limbii literare (sau orice alt nivel) nu poate fi raportat la aceasta, deoarece vorbitorul unui dialect nu este un vorbitor al limbii literare (sau al unui alt dialect), care să se abată ocazional (în dialectul propriu) de la norma altui dialect sau a limbii literare.

Desigur, distincția între desemnat și semificat este o condiție necesară în orice demers lexicologic. O lectură a hărților fără receptarea corectă a informațiilor din legendă, care pot indica anumite valori ale termenilor, ar putea conduce la o falsă nomenclaturizare a unor anumite zone ale lexicului dialectal (p. 39). O citire onomasiologică pe baza titlului hărții, fără urmărirea informației din legendă, urmată de o interpretare semasiologică a răspunsurilor este de neacceptat pentru un lingvist (p. 38). O documentare lexicală semasiologică prin întrebări indirecte, de tipul „La ce ziceți?” sau „Ce înseamnă?” (p. 67), poate clarifica răspunsul inițial. O astfel de cunoaștere, bazată pe principiile cîmpurilor lexicale coseriene, unde cuvîntul poate fi abordat și ca parte a unui întreg, a unui cîmp (p. 28), conduce la ceea ce autorul numește „hartă lexicală semantică”, unde cuvintele care fac parte dintr-un cîmp semantic nu mai sînt prezentate în hărți separate, ci pe aceeași hartă, cu indicarea trăsăturii semantice distinctive pentru fiecare termen din cîmp. Această problematică este tratată detaliat în cazul opoziției sîmbure ${ }^{1}$ : sîmbure $^{2}$ (sîmbure ${ }^{1}$ : miez și os : sîmbure ${ }^{2}$ ) și a celor pentru conceptele 'fratele soției', 'soțul surorii' și 'soțul surorii soției', incluse în cumnat la nivelul limbii literare, dar combinate în mai multe moduri la nivelul dialectului bănățean prin cîte doi termeni pentru cele trei concepte. $\mathrm{O}$ asemenea abordare este cu siguranță cea mai indicată pentru o imagine clară a materialului dialectal, însă ar fi necesară o nouă anchetă pentru fiecare detaliu de acest fel. De altfel, acest detaliu (trăsătura semantică prin care se face diferența specifică) lipsește chiar în obiecția adusă de autor la răspunsul găleată, menționat mai sus, pentru că ar fi trebuit să ni se spună ce anume înțelege prin găleată. Presupunem că este vorba despre răspunsul la întrebarea 917 („Cum îi ziceți vasului făcut din doage, în care mulgeți laptele de la oi?”). La fel, în exemplul dat de noi mai sus, întrebarea cu răspunsurile ceaun, căldare, căldăruşă și căldăruțăa, este necesară definirea raportului între ceaun și căldare, acolo unde răspunsul este ceaun, dar și cel dintre căldăruşă / căldăruță și căldare, acolo unde răspunsul e unul dintre cele două diminutive, unde e posibil să fie o opoziție bazată pe informația morfologică 
(ca în cazul lui călduț / căldicel în exprimarea temperaturii). De asemenea, acolo unde răspunsul este căldare, este de așteptat ca opoziția cu găleată să fie diferită față de celelalte zone. Realizarea unor astfel de hărți presupune o atenție deosebită pentru acest tip de raporturi (ceea ce prespune, pe lîngă abordarea onomasiologică tradiţională, o abordare semasiologică și o lectură semantică), însă rezultatele ar fi cu adevărat incomparabil mai bune față de cele redate prin metoda tradițională. Rezultatul ar fi, utilizînd cîteva concepte coseriene, decelarea „structurii” fiecărui grai și relevanța sa la nivelul ,arhitecturii” limbii „istorice”.

O circumstanță care poate conduce într-adevăr la confuzii, atrage atenția autorul, este modul în care este formulată întrebarea indirectă. De exemplu, întrebarea pentru termeni de înrudire „formulată prin «Cum îi zici [...]?» și nu «ce-ți este [...]??»" poate conduce la termeni de adresare, şi nu la termeni de rudenie (p. 57-58, cf. și p. 54).

În afară de aceste probleme metodologice teoretice (dar cu rezultate practice) sînt prezentate și cîteva probleme de metodologie strict practică: citirea superficială a informațiilor din atlase (sau lipsa lor, îndeosebi în cele pentru Transilvania, unde legenda e foarte sumară sau inexistentă) sau citirea neglijentă a datelor din anchetă de către realizatorul atlasului și trecerea rezultatelor din astfel de lecturi în Dicţionarul limbii române (DLR). Autorul dă exemple chiar și din propriile lucrări, arătînd întregul traseu al apariției şi perpetuării unei erori. Pe parcursul lucrării apar atenționări în privința a diverse probleme, cum ar fi explicații sincronice în DLR, unde ar trebui să fie explicații diacronice (p. 79), centrarea anchetei pe sistemul semantic al vorbitorului (p. 71, 82), utilitatea trecerii în subsolul hărţii a „corespondentului diacronic" (p. 23), toate de un real folos în cercetarea unei limbi istorice. Un scurt capitol (p. 109-121), dar cu informații prețioase, este dedicat documentării interogative a gesturilor.

Lucrarea lui I. Mării poate aduce o contribuție importantă în domeniul dialectologiei și, implicit, al lexicografiei. Chiar dacă uneori apar interpretări prea radicale (așa cum am indicat mai sus), acestea trebuie înțelese în spiritul obiectivului propus, iar „critica evaluativă constructivă” nu trebuie să se limiteze doar la autorul lucrării, ci trebuie asumată și de cititorul ei. Harta lexicală semantică ar trebui să nu lipsească din bibliografia minimală a unui dialectolog, lexicolog sau lexicograf, ceea ce ar îmbunătăţi în mod evident orice lucrare de dialectologie sau de lexicografie. Autorul este conştient de faptul că o aplicare generală a acestei metode pentru un nou atlas lingvistic al României și pentru un nou dicționar al limbii române este greu de realizat (specificăm aici că nici nu poate fi aplicată întregului lexic, pentru că astfel de opoziții se stabilesc numai în anumite zone ale lexicului), însă aplicarea „măcar pentru sistemele semanticoterminologice fundamentale" este un deziderat pe deplin justificat. 